\title{
Delay Identification of the HVAC Project on West Madura Offshore Oil Company Using the House of Risk Method
}

\author{
Gunawan Kunto Bhasworo ${ }^{1}$, and Ervina Ahyudanari ${ }^{2}$ \\ ${ }^{1}$ Department of Technology Management, Institut Teknologi Sepuluh Nopember, Surabaya \\ ${ }^{2}$ Department of Civil Engineering, Institut Teknologi Sepuluh Nopember, Surabaya \\ e-mail: gunawankb@gmail.com
}

\begin{abstract}
Abstrak-This research is focused on the analysis of delays or risks to the implementation of the "Procurement and Installation HVAC Installation" contract at West Madura Offshore Oil Company, which has a working area in the Offshore area. This study uses the HOR (House of Risk) method as an alternative to the ISO31000: 2009 risk management method that has been used internally by West Madura Offshore Oil Company The basis for selecting the HOR (House of Risk) method is the existence of a tool to see the impact (severity) and relations (relations) between the event of a delay and the factoring agent. In identification of the cause of the delay the method used are collecting data primary through Focus Group Discussion between Internal Expert and Secondary data which use project data for Offshore HVAC Project in the period of the year 2016-2018. The HOR (House of Risk) method in conducting this process is presented as follow review historical data and related document, Focus Group Discussion as information gathering techniques, Risk analysis and Risk Register. There are five significant risks from the results of research using the HOR (House of Risk) method, namely Poor-quality shop and coordination drawings, weather constraints, limited quantity and quality of HR (contractors and subcontractors), Absence of duct fabrication workshops at the site and lack of communication between contractor and subcontractor.
\end{abstract}

Keywords-Risk Management, House Of Risk, HVAC, Delay Analysis, Offshore.

\section{INTRODUCTION}

$\mathrm{P}$ ROJECT risk is an uncertain event or condition which, if it occurs, has a positive or negative effect on the project objectives [1]. Projects with broad complexity and strategic importance occur in oil and gas industry construction projects. Risk of conditions in the Oil and Gas field which is a hazardous area, which requires special requirements both for electrical mechanical construction and installation. In NFPA and ICEE there are HVAC (Heating Ventilation Air Conditioning) cooling system requirements as a cooling system as well as a pressurized system. and consists of several subsystems, primarily: thermodynamic processing and filtration, water separation, hot, cold, steam, or water supply for humidification, air duct installation, automatic adjustment subsystem [2].

West Madura Offshore Oil Company is one of the Indonesian Oil and Gas PSC Contractors, one of West Madura Offshore Oil Company Platforms require the work "Procurement and Installation of HVAC" which has been carried out from 2016 to 2018. In its implementation, there was a delay of 382 days. The loss resulted from the delay in the work of "Procurement and Installation of HVAC" in terms of West Madura Offshore Oil Company, namely in terms of lost opportunity cost recovery valued at IDR 9,574,600,000. This delay is caused by delays in the Manufacturing Heating Ventilation Air Conditioning (HVAC) unit, Fabrication Ducting, and Installation processes in the Offshore area.

The delay factor in the Heating Ventilation Air Conditioning (HVAC) work is not only caused by factors in construction but operational problems that hinder the completion of a project such as lack of resources, improper allocation of resources, delays in project implementation, and other problems outside the schedule. in the work plan [3].

Assaf et al. state that the causes of delays include, among others, material, labor, equipment, costs, changes in design changes, relationships with related agencies, scheduling and control, slow monitoring and testing procedures used in the project, environment, contractual issues, and the absence of consultant's professional managers [4].

Internal West Madura Offshore Oil Company has implemented a risk management approach with ISO 31000: 2009 standards as a tool or tool in risk management. The aspect of project delay risk is not reflected in the implementation of ISO31000: 2009 risk management of West Madura Offshore Oil Company Therefore in this study the authors tried to use the HOR (House of Risk) method developed as an alternative method to find the causes or risk identification [5].

\section{METHOD}

Risk management always begins with risk identification, which may be considered the most important phase of the risk management process. The aim of risk factor identification is to comprehensively identify all significant sources of factors affecting a certain project's objective, as well as the causes of those factors [6].

That's why this study utilized Focus Group Discussion. Focus Group Discussion were conducted by Internal Expert from West Madura Offshore Oil Company for the purpose of identifying the risk which is part of risk management process.

The risk management process begins by setting the scope of the "Procurement and Installation of HVAC Project" to be managed at risk. Furthermore, risk identification activities are carried out to determine the potential hazards that may arise 
The $6^{\text {th }}$ International Seminar on Science and Technology (ISST) 2020

July $25^{\text {th }}, 2020$, Institut Teknologi Sepuluh Nopember, Surabaya, Indonesia

Table 1.

Profile of Respondents as Internal Experts

\begin{tabular}{lcc}
\hline \hline Stakeholder & Number of Respondents & Work Experience (years) \\
\hline Engineering & 1 & $5-10$ \\
Project Executor & 3 & $10-15$ \\
QA\&QC Project & 2 & $5-10$ \\
Process Safety & 1 & $5-10$ \\
Field Engineer & 2 & $5-10$ \\
Line Manager Technical Maintenance & 1 & $10-15$ \\
\hline \hline
\end{tabular}

Table 2.

HOR Model 1

\begin{tabular}{|c|c|c|c|c|c|c|c|c|c|}
\hline \multirow[b]{2}{*}{ Business Process } & \multicolumn{9}{|c|}{ Risk Agent (Aj) } \\
\hline & $\begin{array}{c}\text { Risk Event } \\
\text { (Ei) }\end{array}$ & A1 & $\mathrm{A} 2$ & A3 & A4 & A5 & A6 & A7 & $\begin{array}{c}\text { Severity of } \\
\text { Risk Event } i \\
\text { (Si) }\end{array}$ \\
\hline \multirow{2}{*}{ Plan } & E1 & R11 & $\mathrm{R} 12$ & R13 & .. & .. & .. & .. & $\mathrm{S} 1$ \\
\hline & E2 & $\mathrm{R} 21$ & $\mathrm{R} 2$ &.. & .. & .. & .. & .. & $\mathrm{S} 2$ \\
\hline \multirow{2}{*}{ Source } & E3 & $\mathrm{R} 31$ & .. &.. & .. &.. & .. & .. & $\mathrm{S} 3$ \\
\hline & $\mathrm{E} 4$ & $\mathrm{R} 41$ &.. & .. &.. & .. &.. & .. & S4 \\
\hline \multirow{2}{*}{ Make } & E5 &.. &.. &.. &.. &.. & .. & .. & S5 \\
\hline & E6 &.. &.. & .. & .. & .. &.. & .. & S6 \\
\hline \multirow{2}{*}{ Deliver } & E7 &.. &.. & .. & .. & .. &.. & .. & S7 \\
\hline & E8 &.. &.. & .. &.. &.. &.. &.. & S8 \\
\hline Return & E9 &.. &.. &.. &.. &.. &.. &.. & S9 \\
\hline \multicolumn{2}{|c|}{ Occurance of Agent $j$} & $\mathrm{O} 1$ & $\mathrm{O} 2$ & $\mathrm{O} 3$ & $\mathrm{O} 4$ & O5 & O6 & O7 & \\
\hline \multicolumn{2}{|c|}{ Aggregate Risk Potential $j$} & ARP1 & ARP2 & ARP3 & ARP4 & ARP5 & ARP6 & ARP7 & \\
\hline \multicolumn{10}{|c|}{ Priority Rank of Agent $j$} \\
\hline
\end{tabular}

Table 3.

Twenty (20) significant risk factors for the HVAC Systems project., "Risks Affecting the Delivery of HVAC Systems: Identifying and Analysis

\begin{tabular}{|c|c|c|c|c|c|}
\hline Risk Factors classification & RFIT & Rank & RFIC & Rank & Group \\
\hline Poor selection of valves that might cause more damage & 0,449 & 1 & 0,459 & 1 & B \\
\hline Lack of specialized laborers & 0,417 & 2 & 0,355 & 5 & $\mathrm{D}$ \\
\hline Poor-quality shop and coordination drawings & 0,417 & 3 & 0,371 & 3 & $\mathrm{D}$ \\
\hline Wrong selections that might cause future rectification & 0,406 & 4 & 0,415 & 2 & $\mathrm{C}$ \\
\hline Poor safety regulations & 0,385 & 5 & 0,344 & 8 & $\mathrm{D}$ \\
\hline Wrong work procedure between different disciplines & 0,367 & 6 & 0,318 & 12 & $\mathrm{D}$ \\
\hline Equipment sizes clash with provided spaces & 0,363 & 7 & 0,358 & 4 & $\mathrm{C}$ \\
\hline Wrong selection of dampers and plenum boxes & 0,339 & 8 & 0,337 & 11 & A \\
\hline Power/Chilled/Duct connection might not match with the equipment & 0,338 & 9 & 0,34 & 9 & $\mathrm{C}$ \\
\hline Openings missing in the concrete and wall for horizontal and vertical penetration & 0,337 & 10 & 0,278 & 15 & $\mathrm{D}$ \\
\hline Selecting fittings that might not be compatible with the pipe thickness & 0,336 & 11 & 0,352 & 6 & $\mathrm{~B}$ \\
\hline Weak connection/ joints (threaded/ groove/ welded etc.) between two chilled water pipe pieces & 0,334 & 12 & 0,347 & 7 & B \\
\hline Inappropriate storage of the duct, which might cause damage to the duct & 0,329 & 13 & 0,254 & 22 & A \\
\hline Unsafe handling of the equipment & 0,312 & 14 & 0,338 & 10 & $\mathrm{C}$ \\
\hline Installation without following the standard procedure & 0,312 & 15 & 0,275 & 16 & $\mathrm{D}$ \\
\hline Extreme weather conditions & 0,311 & 16 & 0,27 & 18 & $\mathrm{D}$ \\
\hline Shortage of power supply for machine's operation & 0,311 & 17 & 0,252 & 24 & $\mathrm{D}$ \\
\hline Lack of water supply and drainage for testing & 0,308 & 18 & 0,253 & 23 & $\mathrm{~B}$ \\
\hline Abnormal floor height that might require special scaffolding & 0,304 & 19 & 0,26 & 21 & $\mathrm{D}$ \\
\hline Inappropriate fixing methods & 0,301 & 20 & 0,278 & 14 & $\mathrm{D}$ \\
\hline
\end{tabular}

and also do historical data collection from the project in the 2016-2018 implementation period. In this stage a list of delays will be generated that can be obtained from the identification of the source of the delay, what are the factors of delay (what), where the delay factor appears / is found (where), how the delay arises in that place (how) and why the delay arises (why), which delay has an impact on the achievement of company goals and objectives within the scope of the "Procurement and Installation of HVAC" projects.

\section{A. Data Collection}

Data collection will be divided into two with detail;(1)Primary Data, starting with setting the scope of the "Procurement and Installation of HVAC Project" to be managed at risk, then conducting Focus group discussions and Internal Expert Judgments using secondary data as a basis for discussion;(2)Secondary data, the collection of similar project history data (HVAC) at West Madura Offshore Oil Company in the period of 2016-2018 as secondary data.

In determining the weighting criteria in this study will be carried out through an expert judgment process with the profile of respondents can see Table 1. Respondents in table 1 are internal stakeholders involved in the HVAC project in the 2016-2018 period and are also experts at WEST MADURA OFFSHORE OIL COMPANY has experience in fields related to the HVAC project.

After conducting a focus group discussion, the researcher does the re-recording for further re-verification so that the definition of the researcher from the results of the focus group 
The $6^{\text {th }}$ International Seminar on Science and Technology (ISST) 2020

July $25^{\text {th }}, 2020$, Institut Teknologi Sepuluh Nopember, Surabaya, Indonesia

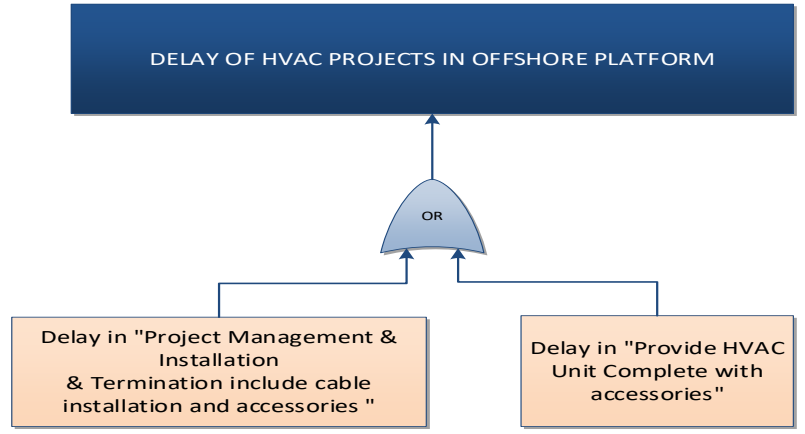

Figure 1. FTA (Fault Tree Analysis) level 1 identification of the delay in the results of the FGD (Focus Group Discussion)

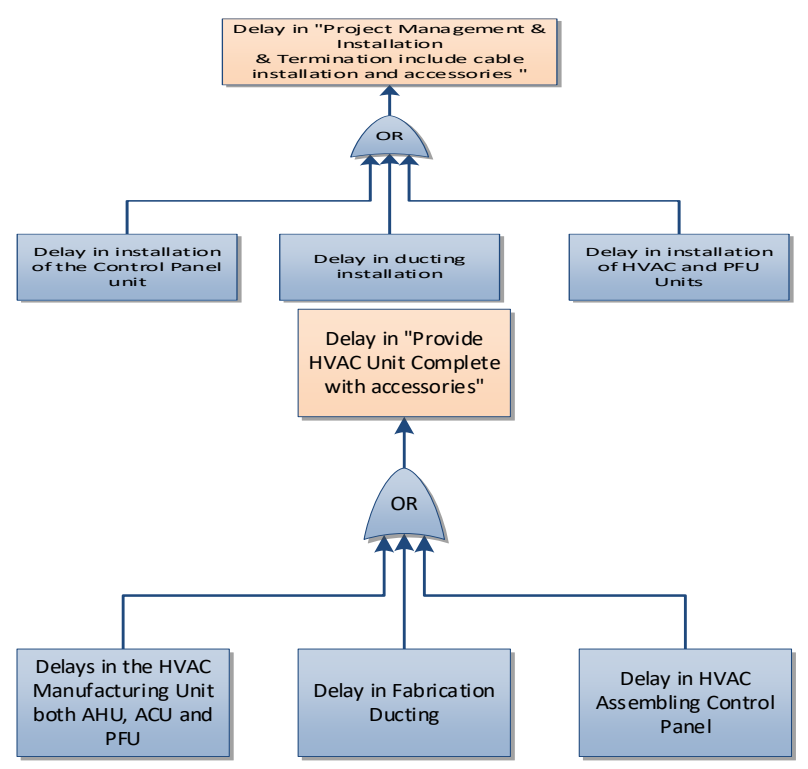

Figure 2. Level 2 FTA (Fault Tree Analysis) identification of the delay in the results of the FGD (Focus Group Discussion).

discussion can be believed to be in accordance with the objectives and research objects.

\section{B. Risk Identification or Delay Stage}

Risk identification activities carried out to determine the potential hazards that may arise. The common tools and techniques used are:

a. Review documents: Input documents in the pre-project stage (Pre-FS / FS documents, economic models, risk evaluation results, and other supporting documents.

b. Information Gathering Techniques which will be used are: Focus Group Discussion.

c. Analysis Checklist

d. Root Cause Analysis, which will be used is FTA basis from the Internal Expert Judgment of West Madura Offshore Oil Company. After getting the risk based on the risk identification process, next step is using House ofRisk (HOR) method for the identification of the delay stage. The detail step are:

a. Identification of possible delays that may occur for each stakeholder, obtained from the focus group discussion

b. Give a rating on a scale of 1 to 5 regarding the severity due to factors that occur delays

c. Identify agents of delays and assess their likelihood.

d. Develop a linkage matrix (relations) between each of the delay factor agents with each delay.
Table 4.

Likert scale for severity used in the HOR (House of Risk) approach

\begin{tabular}{ll}
\hline \hline Scale & Remark \\
\hline 5 & Very serious impact and cause project failure \\
4 & Serious impact on project completion \\
3 & Moderate impact on project completion \\
2 & Little impact on project completion \\
1 & The impact on the completion time target can be ignored \\
\hline \hline
\end{tabular}

Table 5.

Likert scale for probability used in the HOR (House of Risk) approach

\begin{tabular}{ll}
\hline \hline Scale & Remark \\
\hline 6 & $\begin{array}{l}\text { Probabilities inevitably occur and } \\
\text { cause project failure }\end{array}$ \\
5 & $\begin{array}{l}\text { The probability of occurrence is very high } \\
\text { so it is very common for projects }\end{array}$ \\
4 & High probability of occurrence \\
3 & Probability of moderate occurrence \\
2 & low probability of occurrence \\
1 & the probability of occurrence \\
& will almost certainly not occur
\end{tabular}

Table 6.

Severity rating value for delay events in the HOR (House of Risk) metho

\begin{tabular}{lll}
\hline \hline Code & Delay Event & Severity \\
\hline E1 & $\begin{array}{l}\text { Delay in HVAC Manufacturing Units } \\
\text { both AHU, ACU and PFU }\end{array}$ & 4 \\
E2 & Delay in Fabrication Ducting & 4 \\
E3 & Delay in the HVAC Assembly Control Panel & 3 \\
E4 & Delay in installation of the Control Panel unit & 3 \\
E5 & Delay in ducting installation & 4 \\
E6 & Delay in installation of HVAC and PFU Units & 4 \\
\hline \hline
\end{tabular}

e. Calculate the Aggregate Delay Potential of Agent $j$ (ADPj) which is the result of the possible emergence of the delay factor $j$ agent and the aggregate effect of the delay caused by the delay factor agent.

$\mathbf{A R P j}=\mathbf{O j} \sum \mathbf{i S i R i j}$.

f. Rank the delay factor by the aggregate risk potential from the largest value to the smallest value.

g. Use Pareto Chart 80:20 with $\mathrm{ARP}_{\mathrm{j}}$ as basis calculation using formula :

Pareto $=($ ADPj/TotalADP $) \times 100 \%$

HOR Model 1 can see Table 2.

\section{RESULT AND DISCUSSIONS}

\section{A. Identification of Late Events}

The primary data obtained from this identification came from focus group discussions with internal expert judgment consisting of engineering, project executors, QA \& QC projects, process safety, field engineers, and Line Manager Technical Maintenance as Contract Holder in the "Procurement and HVAC Installation "Button. And secondary data obtained from the literature review and historical data of the company must be able to describe events, risk agents (include sources of risk), potential consequences, and key risk indicators.

The Literature Review that will be used is a paper entitled Risks affecting the delivery of HVAC systems: Identifying and analysis [7] which describes the risks in HVAC construction projects, a list of risks contained in this paper can be seen in Table 3. To determine the severity and probability of the risk, a Likert scale is used in the HOR 
The $6^{\text {th }}$ International Seminar on Science and Technology (ISST) 2020

July $25^{\text {th }}, 2020$, Institut Teknologi Sepuluh Nopember, Surabaya, Indonesia

Table 7.

the probability or occurrence for delay agents in the HOR (House of Risk) method

\begin{tabular}{lll}
\hline \hline Code & Delay Agent & Occurrence \\
\hline A1 & Complicated delivery and inspection procedures & 2 \\
A2 & Weather Constraints & 5 \\
A3 & Difficult access in "horizontal and vertical penetration" of the walls of the room & 2 \\
A4 & Limited quantity and quality of human resources (contractors and subcontractors) & 4 \\
A5 & Limitations of POB (Personal on Board) on PT.XYZ's Offshore Platform & 3 \\
A6 & Absence of duct fabrication workshop at the site & 6 \\
A7 & Lack of communication between contractor and sub-contractor \\
A8 & Lack of storage space for ducts, pipes, and equipment at the site \\
A9 & Logistic difficulties in shifting the ducts, pipes, and equipment to the storage area & 5 \\
A10 & Poor-quality shop and coordination drawings & 6 \\
A11 & Low performance / productivity of contractors & 5 \\
A12 & Safety Regulations for Offshore work & 4 \\
\hline \hline
\end{tabular}

Table 8.

Listing or listing of agents causing delays in the delay event with E1 code that will be used in the HOR (House of Risk) Method

No Event Delay $\quad$ Delay Agent

E1 Delay in HVAC Manufacturing Units both AHU, ACU, and PFU
Limited quantity and quality of human resources (contractors and subcontractors)

Complicated delivery and inspection procedures

Lack of communication between contractors and subcontractors Poor-quality shop and coordination drawings

Logistical difficulties in shifting the ducts, pipes, and equipment to the storage area

Table 9.

Listing or listing of agents causing delays in the delay event with the E2 code that will be used in the HOR (House of Risk) Method

\begin{tabular}{ccc}
\hline No & Event Delay & Delay Agent \\
\hline E2 & Delay in ducting Fabrication & $\begin{array}{l}\text { Limited quantity and quality of human resources (contractors and subcontractors) } \\
\text { Lack of communication between contractors and subcontractors } \\
\text { Poor-quality shop and coordination drawings }\end{array}$ \\
\hline \hline No & Listing or listing of agents causing delays in the delay event with the E3 code that will be used in the HOR (House of Risk) Method & Table 10. \\
\hline E3 & Delay in HVAC Assembling Control Panel Agent & $\begin{array}{l}\text { Lack of communication between contractors and subcontractors } \\
\text { Poor-quality shop and coordination drawings } \\
\text { Limited quantity and quality of human resources (contractors and subcontractors) }\end{array}$ \\
\hline \hline
\end{tabular}

(House of Risk), with details as follows: (a) For the severity, the Likert scale will be used as in table 4 ; (b) 2 . For the probability or probability number, the Likert scale will be used as in table 5.

The FGDs result that have been carried out with Fault Tree Analysis (FTA) are events and agents and sub-agents of delays related to delays from the project "Procurement and Installation of HVAC (Heating Ventilation Air Conditioning)" which show in figure 1 and 2.

From Figure 1 and 2 we can know factors that cause (can be called a Delay Event) of the project "Procurement and Installation of HVAC (Heating Ventilation Air Conditioning)", namely:

\section{1) Delay "Project Management \& Installation \& Termination}

Delay "Project Management \& Installation \& Termination including cable installation and accessories", which has a delay agent:

a. Delay in the installation of the Control Panel unit

b. Delay in ducting installation c. Delay in the installation of the HVAC Unit (Heating Ventilation Air Conditioning) and PFU (Pressurize Fan Unit).

2) Delay "Provide HVAC Unit Complete with accessories

Delay "Provide HVAC Unit Complete with accessories", which has a delay agent:

a. Delay in HVAC (Heating Ventilation Air Conditioning) Manufacturing Unit both AHU (Air Handling Unit), ACU (Air Conditioning Unit) and PFU (Pressurize Fan Unit).

b. Delay in Fabrication Ducting

c. Delay in HVAC (Heating Ventilation Air Conditioning) Assembly Control Panel

Furthermore, the probability or occurrence value of delay agent and severity or impact severity of each event delay can be seen in table 6 and 7 .

From the table 6 and 7 it is known that the HOR (House of Risk) method uses table 4 and 5 as a scale to determine the severity impact and that will be used to obtain risk ratings through Aggregate Delay Potential (ADP) calculations which the matrix is shown in table 2 . 
The $6^{\text {th }}$ International Seminar on Science and Technology (ISST) 2020

July $25^{\text {th }}, 2020$, Institut Teknologi Sepuluh Nopember, Surabaya, Indonesia

Table 11.

Listing or listing of agents causing delays in the delay event with the E4 code that will be used in the HOR (House of Risk) Method

\begin{tabular}{|c|c|c|}
\hline No & Event Delay & Delay Agent \\
\hline E4 & Delay in the installation of the Control Panel unit & $\begin{array}{l}\text { Limitations of POB (Personal on Board) on PT.XYZ's Offshore Platform } \\
\text { Limited quantity and quality of human resources (contractors and subcontractors) } \\
\text { Safety Regulations for Offshore work } \\
\text { Weather Constraints }\end{array}$ \\
\hline \multicolumn{3}{|c|}{$\begin{array}{l}\text { Table } 12 \text {. } \\
\text { Listing or listing of agents causing delays in the delay event with the E } 5 \text { code that will be used in the HOR (House of Risk) Method }\end{array}$} \\
\hline No & Event Delay & Delay Agent \\
\hline E5 & $\begin{array}{l}\text { Limited quantit } \\
\text { Safety Regulati } \\
\text { Weather Const } \\
\text { Poor-quality sh } \\
\text { Absence of du } \\
\text { Difficulties in " }\end{array}$ & $\begin{array}{l}\text { y and quality of human resources (contractors and subcontractors) } \\
\text { ons for Offshore work } \\
\text { aints } \\
\text { op and coordination drawings } \\
\text { t fabrication workshop at the site } \\
\text { horizontal and vertical penetration" against the walls of the room }\end{array}$ \\
\hline
\end{tabular}

Table 13.

Listing or listing of agents causing delays in delay events with code E6 that will be used in the HOR (House of Risk) Method

\begin{tabular}{|c|c|c|}
\hline No & Event Delay & Delay Agent \\
\hline E6 & Delay in the installation of HVAC and PFU Units & $\begin{array}{l}\text { Limitations of POB (Personal on Board) on PT.XYZ's Offshore Platform } \\
\text { Limited quantity and quality of human resources (contractors and subcontractors) } \\
\text { Safety Regulations for Offshore work } \\
\text { Weather Constraints } \\
\text { Difficult access in "horizontal and vertical penetration" of the walls of the room } \\
\text { Lack of storage space for ducts, pipes, and equipment at the site }\end{array}$ \\
\hline
\end{tabular}

Table 14.

ADP (Aggregate Delay Potential) results on the HOR (House of Risk)

\begin{tabular}{|c|c|c|c|c|c|c|c|c|c|c|c|c|c|}
\hline Business Process & $\begin{array}{c}\text { Risk } \\
\text { Event } \\
(\mathrm{E} i)\end{array}$ & A1 & $\mathrm{A} 2$ & A3 & A4 & A5 & A6 & A7 & A8 & A9 & A10 & A11 & $\begin{array}{c}\text { Severity } \\
\text { of } \\
\text { Risk } \\
\text { Event } i \\
\text { (Si) }\end{array}$ \\
\hline \multirow{4}{*}{ Provide HVAC unit } & E1 & 3 & 0 & 0 & 3 & 0 & 0 & 3 & 0 & 9 & 9 & 0 & 4 \\
\hline & E2 & 0 & 0 & 0 & 3 & 0 & 0 & 3 & 0 & 0 & 9 & 0 & 4 \\
\hline & E3 & 0 & 0 & 0 & 3 & 0 & 0 & 3 & 0 & 0 & 9 & 0 & 3 \\
\hline & E4 & 0 & 9 & 0 & 3 & 3 & 0 & 0 & 0 & 0 & 0 & 1 & 3 \\
\hline \multirow[t]{2}{*}{ Project Management and Installation } & E5 & 0 & 9 & 0 & 3 & 3 & 9 & 0 & 0 & 0 & 9 & 1 & 4 \\
\hline & E6 & 0 & 9 & 1 & 3 & 3 & 0 & 0 & 3 & 0 & 0 & 1 & 4 \\
\hline Occurance of Agent $j$ & & 2 & 5 & 2 & 4 & 3 & 6 & 5 & 6 & 4 & 5 & 2 & \\
\hline Aggregate Risk Potential $j$ & & 24 & 495 & 8 & 264 & 99 & 216 & 165 & 72 & 144 & 675 & 22 & \\
\hline Priority Rank of Agent $j$ & & 9 & 2 & 11 & 3 & 7 & 4 & 5 & 8 & 6 & 1 & 10 & \\
\hline
\end{tabular}

Table 15.

Ranking or ranking of Pareto results from the ADP (Aggregate Delay Potential) on the HOR (House of Risk) method

\begin{tabular}{lllll}
\hline $\begin{array}{l}\text { Agent } \\
\text { Code }\end{array}$ & Aggregate Risk Potential $j$ & $\begin{array}{l}\text { Priority Rank of } \\
\text { Agent } \mathrm{j}\end{array}$ & Cumulative Percen & Delay Agent \\
\hline A10 & 675 & 1 & $31 \%$ & $\begin{array}{l}\text { Poor-quality shop and coordination } \\
\text { drawings } \\
\text { A2 }\end{array}$ \\
495 & 2 & $54 \%$ & $\begin{array}{l}\text { Weather Constraints } \\
\text { Limited quantity and quality of } \\
\text { human resources } \\
\text { (contractors and subcontractors) }\end{array}$ \\
A4 & 264 & 3 & $66 \%$ & $\begin{array}{l}\text { Absence of duct fabrication } \\
\text { workshop at the site } \\
\text { Lack of communication between } \\
\text { contractors and subcontractors }\end{array}$ \\
\hline A6 & 216 & 4 & $76 \%$ & $83 \%$ \\
\hline
\end{tabular}

\section{B. Identification of Agents Causing Delays}

After finding the event or event causing the delay, the next step is to find the agent and sub-agent causing the delay. With primary and secondary data obtained. Then get several agents and sub-agents causing delay using the FTA (Fault Tree An alysis) method and Focus Group Discussion (FGD), the result are shown in the following Table 8, 9, 10, 11, 12 and 13.

\section{Analysis of Research Result Based on the Method Used}

Based on the results of the research that has been done in the previous sub-chapter both about the significant potential 
The $6^{\text {th }}$ International Seminar on Science and Technology (ISST) 2020

July $25^{\text {th }}, 2020$, Institut Teknologi Sepuluh Nopember, Surabaya, Indonesia

risks that cause delays in the Project "Procurement and Installation of HVAC (Heating Ventilation Air Conditioning)" on the WEST MADURA OFFSHORE OIL COMPANY Offshore Platform or risk mitigation to deal with it using the Risk Management method The ISO31000: 2009 approach and HOR (House of Risk) are obtained potential significant risks that cause delays in the Project "Procurement and Installation of HVAC (Heating Ventilation Air Conditioning)" on the Offshore Platform of PT.XYZ, like seen in table 14 and 15. From table 15, we can resume:

\section{1) Poor-quality shop and coordination drawings}

"Poor-quality shop and coordination drawings" which have the largest quantitative impact of five hundred twenty-two (522) thousand USD, an RPN (Risk Priority Number) of fifteen (15) or in the category of High Impact, and a percent value of Pareto diagram of $31 \%$. Thirty-one percent (31\%) shows the largest contribution compared to other risks. The delay agent "Poor-quality shop and coordination drawings" ranks third of the twenty list of risk factors causing delays in the HVAC project [7].

\section{2) Weather constraints}

Weather constraints "which have an RPN (Risk Priority Number) of sixteen (16) or with the High Impact category, and a percent value of a pareto diagram of $23 \%$. The value of twenty-three percent (23\%) shows the second largest contribution compared with other risks. This is caused by the transportation and accommodation system in the offshore area which is very dependent on weather conditions.

\section{3) Limitations on the quantity and quality of human} resources (contractors and subcontractors

"Limitations on the quantity and quality of human resources (contractors and subcontractors)" which have an RPN (Risk Priority Number) of twenty (20) or with a High Impact category, and a percent value of a pareto diagram of $12 \%$. The value of twelve percent $(12 \%)$ shows the third largest contribution compared to other risks. This is caused "Limited quantity and quality of human resources (contractors and subcontractors)" is common or often occurs in every construction project and were identified as the factors most causing project delay [6].

\section{4) Absence of duct fabrication workshop at the site}

"Absence of duct fabrication workshop at the site" where the RPN (Risk Priority Number) value is twenty (20) or with the category of High Impact, the percent value of the pareto diagram is $10 \%$. The value of ten percent $(10 \%)$ shows the fourth largest contribution compared with other risks. Delay agent "Absence of duct fabrication workshop at the site" is the uniqueness of HVAC construction work in Oil and Gas companies located in offshore areas, in addition to limited space, hazardous area location is another factor that causes no duct fabrication workshop ".

\section{5) The lack of communication}

"The lack of communication between the contractor and the sub-contractor which has an RPN (Risk Priority Number) of nine (9) or with the Moderate Impact category, and the percent value of the Pareto diagram is $7 \%$. A value of seven percent $(7 \%)$ shows the fifth largest contribution compared with other risks, this is in the correlation between three (3) delay events with codes E1 through E3 with a correlation value of three (3) or with categories according to the Likert scale "low". This is caused "Limited quantity and quality of human resources (contractors and subcontractors)" is common or often occurs in every construction project.

\section{CONCLUSION}

After numerous proses including FGD (focus group discussion), this study has identified the risk factors that affect the duration and cost of the identified activities for the purpose of high-lighting the key risks that can significantly influence the delivery of HVAC systems in offshore construction projects. The outcome of the study is a list of five (5) significant risk factor which fall to category Manufacturing or Fabrication and Installation. A summary of the specific conclusions drawn from this study is as follows:(a)The result from FGD regarding the ranking of risk factors were determined based on three indices related to the probability of occurrence, impact and the inherent quantitative impact. The experience of the respondents was taken into consideration; (b)Severity scale indices were developed based on a combination of the probability of occurrence and the impacts of risk factors on time and cost to describe the key risk factors affecting HVAC system activities; (c)"Poor-quality shop and coordination drawings" was considered the most important risk factor that affected both time and cost. With $31 \%$ shown as the largest contribution compared to other risks, this is due to the high correlation value ( 9 , "high correlation") to the most delay events; (d)Correlation or relationship between risk agents each other are important factor that can determine the risk priority which can lead to accurately risk treatment.

\section{REFERENCES}

[1] P. K. Maheshbhai, R. Bhatt, and J. J. Bhavsar, "A Study of Risk Factors Affecting Building Construction Projects," Int. J. Eng. Res. Technol., vol. 3, no. 12, pp. 831-835, 2014.

[2] M. Porowski, "The optimization method of HVAC system from a holistic perspective according to energy criterion," Energy Convers. Manag., vol. 181, pp. 621-644, 2019, doi 10.1016/j.enconman.2018.11.069.

[3] J. M. Nicholas and H. Steyn, Project Management for Engineering, Business and Technology, 5th ed. London: Taylor \& Francis Group, 2017.

[4] S. A. Assaf and S. Al-Hejji, "Causes of delay in large construction projects," Int. J. Proj. Manag., vol. 24, no. 4, pp. 349-357, 2006, doi: 10.1016/J.IJPROMAN.2005.11.010.

[5] I. N. Pujawan and L. H. Geraldin, "House of risk: a model for proactive supply chain risk management,” Bussiness Process Manag. J., vol. 15 no. 6, pp. 953-967, 2009.

[6] I. P. A. Wiguna and S. Scott, "Nature Of The Critical Risk Factors Affecting Project Performance In Indonesian Building Contracts," in 21st Annual ARCOM Conference, 2005, pp. 225-235.

[7] S. A. A. Mosaad, U. H. Issa, and M. S. Hassan, "Risks affecting the delivery of HVAC systems: identifying and analysis," J. Build. Eng. vol. 16, no. Maret, pp. 20-30, 2018, doi: 10.1016/j.jobe.2017.12.004. 